\title{
Statement by Eduardo Valencia-Ospina
}

\author{
Chair of the International Law Commission at Its Seventieth Session
}

(Translation from the Spanish Original)

It is an honour for me, on behalf of the International Law Commission, to welcome you all to this solemn meeting to mark the beginning of the Commission's seventieth anniversary commemoration. Allow me to thank the dignitaries who have accepted the invitation to speak on this occasion: H.E. Miroslav Lajčák, the President of the General Assembly; Miguel Ferreira de Serpa Soares, the Legal Counsel of the United Nations; H.E. Burhan Gafoor, the Permanent Representative of Singapore and Chair of the Sixth Committee; the representatives of the host countries of the Commission at its seat in Geneva and at the United Nations Headquarters, H.E. Jürg Lauber, the Permanent Representative of Switzerland, and Jennifer Newstead, the Legal Adviser at the Department of State of the United States of America; and Professor Nico Schrijver, the President of the Institut de Droit international.

I would like to express appreciation to all those who have graced us with their presence today: permanent representatives and other members of permanent missions; legal advisers of foreign ministries and permanent missions; senior officials of the Secretariat and representatives of specialized agencies and other international organizations; teachers and students from law faculties and other academic institutions; and former members of the Commission and its secretariat.

Exceptionally, the Commission is holding the first part of its session for 2018 at United Nations Headquarters to mark its seventieth anniversary. By an express decision of the General Assembly - the Commission's founding body the Commission is meeting for five weeks in New York, not far from Lake Success, where it held its first session in 1949. ${ }^{1}$ Thus, the oft-expressed desire of the Sixth Committee, echoed by the Commission, has been made reality, serving to strengthen the already close relationship between the two bodies.

That relationship finds expression, above all, in the resolutions periodically adopted by the General Assembly, which result from the consideration given at each of its regular sessions by the Sixth Committee to the reports submitted to it every year by the Commission. Those reports, 70 to date all told, embody the crucial contribution made by the Commission in the course of its existence to the

1 UNGA Res 72/116 (7 December 2017), para 14. 
progressive development and codification of international law. They provide the clearest evidence of the constructive and effective manner in which the Commission has fulfilled the functions entrusted to it by the Assembly, in accordance with its mandate under Article 13 (1) (a) of the Charter of the United Nations.

The inclusion of that provision in the constituent instrument of the United Nations at the San Francisco Conference was by no means a one-off initiative. On the contrary, it represented a decisive step forward within the "codification movement", the origins of which date back to the late eighteenth century. The movement was given a significant boost with the establishment, in 1873, of the Institut de Droit international and the International Law Association. Those institutions, at twice the age of the Commission, continue to work privately for their shared goal. It is, therefore, all the more significant that, on this seventieth anniversary of the Commission, the President of the Institut has been chosen to deliver the keynote address that will conclude today's solemn meeting.

There is no need here to enumerate the many influential substantive achievements of the Commission on various subjects in the course of its prodigious work down the years. Suffice it to underline that the Commission has addressed, among other crucial issues, the three main sources of international law mentioned in Article 38, paragraph 1, of the Statute of the International Court of Justice. Testimony to that is its final text on the law of treaties, which served as the basis for the Vienna Convention of $1969 .{ }^{2}$ That foundational instrument, which received near-universal endorsement from Member States, has been a rich source of inspiration for the Commission in its own study of a dozen topics arising from the Convention or closely related to it. Likewise, the final text of the draft conclusions on the identification of customary international law, the second of the main sources, which is to be adopted at the current session. The third source, general principles of law, was added as a topic to the Commission's long-term programme of work last year.

It is appropriate mentioning here the accomplishments of the Commission with regard to the topics included in its long-term programme of work. Already at its first session in 1949, the Commission drew up a programme of work comprising 14 topics selected from a list of 25 options contained in the famous Lauterpacht memorandum. ${ }^{3}$ Since 1949 , a further 38 topics, some of them divided into separate sub-topics, have been selected for examination. The nine that make up the

2 Vienna Convention on the Law of Treaties, adopted 23 May 1969, entered into force 27 January 1980, 1155 UNTS 331 .

3 United Nations, 'Survey of International Law in Relation to the Work of Codification of the International Law Commission: Preparatory work within the purview of article 18, paragraph 1, of the of the International Law Commission' (1949) UN Doc A/CN.4/1/Rev.1. 
Commission's current programme of work are under active consideration. Those aside, the Commission has submitted final reports on all but three of the topics that were on the initial list or added subsequently. Upon concluding its work this year, the Committee will submit final reports on two more topics and will complete drafts, adopted on first reading, on another two. Given the progress made on the remaining topics, the Commission may find itself close to completing its current programme of work by the end of the present quinquennium in 2021.

The Commission will, however, from this session onwards continue the ongoing task of selecting topics for future consideration. It should not, as it has largely done in the past, limit itself to traditional topics. Rather, it should consider topics that reflect new developments in international law and the pressing concerns of the international community as a whole, in line with the fourth of the criteria agreed upon in 1998 for the selection of topics. In that regard, it is highly significant that, in accordance with article 17 of its statute and in response to the call in its report of last year, the Commission has received a formal request from a Member State for the inclusion of a new topic responding to a particularly pressing need of a large sector of the international community, to which that State belongs.

It may thus be concluded that the International Law Commission has fully accomplished the noble mission entrusted to it by the community of nations, duly represented by the General Assembly. Its contribution has been fundamental in terms of strengthening the rule of law in international relations, enabling them to evolve since the Second World War from a framework of confrontation to one of cooperation. Today, however, this painstaking yet constructive process towards the achievement of multilateralism is being threatened by the unilateral actions of some major players on the world stage and the outsized role that "national interest" is playing in their exercise of sovereignty.

The duty to cooperate, which lies, explicitly or implicitly, at the heart of the Commission's final outputs and reports, is a well-established principle of international law enshrined in the Charter and the 1970 Declaration on Principles of International Law concerning Friendly Relations and Cooperation among States in accordance with the Charter of the United Nations ${ }^{4}$ and reflected in many other international instruments. It represents the practical expression of the principle of solidarity that, as one former Secretary-General emphasized, "has its roots in the ethical principles of the Charter". ${ }^{5}$ Solidarity provides the

4 UNGA Res 2625 (xxv) (24 October 1970).

5 Report of the Secretary-General, 'New International Humanitarian Order: Humanitarian Assistance to Victims of Natural Disasters and Similar Emergency Situations' (1990) UN Doc A/ $45 / 5^{87}$ para 5 . 
Commission's mandate with its telos, or ultimate purpose, as an expression of a common global legacy. As an international ethical and legal principle, solidarity gives rise to a system of cooperation underpinning the notion that justice and the common good are best served by policies that benefit all nations.

Cooperation should not be interpreted as diminishing the prerogatives of a sovereign State within the limits of international law. On the contrary, the principle emphasizes respect for the sovereignty of States and its corollary, non-intervention and the primary role of State authorities in the adoption of measures of any kind that are expressions of the "right of every sovereign State to conduct its affairs without outside interference", as the International Court of Justice put it in its judgment of 1986 in the case concerning Military and Paramilitary Activities in and against Nicaragua. ${ }^{6}$ The correlating principles of sovereignty and non-intervention presuppose a given domestic sphere, or a domaine réservé, over which a State may exercise its exclusive authority. This sovereign authority remains central to the concept of statehood, but it is by no means absolute. As Judge Alejandro Álvarez made clear in his individual opinion in the Corfu Channel case, "sovereignty confers rights upon States and imposes obligations on them".7 And Martti Koskenniemi, a former member of the Commission, maintained in a recent article that one is most sovereign when one is most intensively engaged with the international world. ${ }^{8}$

The United Nations is the supreme example of a global institution that embodies international cooperation. The Commission itself, a subsidiary body of the General Assembly, is another example, given its mandate covering a broad range of topics of international law, its membership and the way in which its members are elected by the Assembly, which ensures, within the framework of equitable regional representation, compliance with the criteria set forth in article 8 of its statute. Although the Commission is still a long way from achieving gender parity - an imperative goal for international organizations - in the current quinquennium it has the largest number of women members in its history. The Commission also sets an example of cooperation through its working methods, which are designed to facilitate the search for common legal ground on which to build its drafts.

6 Military and Paramilitary Activities in and against Nicaragua (Nicaragua v United States) (Merits) [1986] ICJ Rep 14, 106.

7 Corfu Channel Case (United Kingdom v Albania) (Separate Opinion Judge Alvarez) [1949] ICJ Rep 39, 43 .

8 Martti Koskenniemi, 'The many faces of sovereignty. Introduction to critical legal thinking' (2007) 4(2) KustafinULRev 29o. 
The Commission has played a crucial role in laying the foundations for the proper functioning of the international community in the post-war era. Given the worrying isolationist tendencies that have recently surfaced on the world stage, there is a need, today more than ever, for it to continue its work of consolidating international law, which remains the sturdiest bulwark for ensuring the survival of an international society that all nations have helped to build and from which all have benefited. 